\title{
Making Sense of Uncertainty: An Examination of Environmental Interpretation
}

\author{
Padraic Regan \\ Department of International Business, Irish American University \\ No. 2 Merrion Square, Dublin, Ireland \\ Tel: 353-1-235-3952Ｅ-mail: pregan@eircom.net
}

$\begin{array}{ll}\text { Received: November 17, } 2011 & \text { Accepted: February 9, } 2012 \quad \text { Published: March 16, } 2012 \\ \text { doi:10.5539/ijbm.v7n6p18 } & \text { URL: http://dx.doi.org/10.5539/ijbm.v7n6p18 }\end{array}$

\begin{abstract}
Uncertainty in the environment has implications for an organisation's structures, strategies and processes. By extending an existing uncertainty framework and measuring how it is influenced by strategic decision-making, entrepreneurial orientation and organisation structure, this paper explores the process of environmental interpretation. Hypotheses are formulated for testing on the European airport industry. The results show that a fourth type of uncertainty can be meaningfully added to the existing three-part framework; that the four types should be treated as separate constructs; and that rational strategic decision-making, entrepreneurial orientation and organic organisation structures are positively related to environmental uncertainty. Moreover, these variables exert different levels of influence at different stages of the interpretation process. Implications for management are considered along with study limitations and recommendations for future research.
\end{abstract}

Keywords: Environmental uncertainty, Strategic decision-making processes, Entrepreneurial orientation, Organisation structure

\section{Introduction}

According to Thompson, dealing with uncertainty is the essence of the administrative process (1967: 159). Attempts to manage uncertainty involve "building up interpretations about the environment [which] is a basic requirement of individuals and organizations" (Daft and Weick, 1984: 284). With so many conceptualisations, operationalisations and inconsistent research results over the years, however, there is a danger that the concept of environmental uncertainty has become so stretched as to be rendered "fundamentally meaningless" (Kreiser and Marino, 2002: 895). Milliken's $(1987$; 1990) re-examination of the construct approached this overly-broad conceptualisation issue by decomposing environmental uncertainty into three types, i.e. state, effect and response. This study seeks to build on the work of Milliken by postulating that a fourth type of uncertainty, viz. outcome uncertainty (Gibbons and Chung, 1995), can be added and by identifying the manner in which key organisational characteristics influence the now four component parts of perceived environmental uncertainty, viz. noticing a change, assessing it, responding to it and evaluating the effectiveness of the response. Moreover, as the key objective is to advance our understanding of environmental interpretation, uncertainty is positioned as the dependent variable rather than in its conventional independent / moderator role.

The process of identifying suitable predictors of perceived environmental certainty commenced with Milliken's suggestion that investigating the decision-making processes used in interpreting the environment would be a "useful direction for future research" (Milliken, 1987: 141). The link between strategic decision making processes and the environment was also encapsulated in Daft and Weick's view that "organisations are open social systems that process information from the environment...and then base organizational action on that environment" (1984: 285). The rational model of strategic decision-making was selected as its essential characteristic is comprehensive analysis and interpreting the environment requires obtaining and analyzing substantial volumes of information (Fredrickson, 1984). Similarly, organic organisation structure was chosen as a predictor variable on the basis of its superior information processing capabilities (Burns and Stalker, 1961; Galbraith JR, 1973). Finally, entrepreneurial orientation was deemed an important construct to test as Milliken (1987) also linked perceived environmental uncertainty with levels of diversification into new products and processes. Moreover, Knight (1921) linked the two constructs by describing entrepreneurs as 'organisers of uncertainty'. Thus, the primary objective of this research study is to advance our knowledge by identifying causal linkages between rational strategic decision-making processes, entrepreneurial orientation, organic 
organisation structure, and perceived environmental uncertainty. In essence, the research question being posed is: how do rational strategic decision-making, entrepreneurial orientation and organic organisation structure influence perceived environmental uncertainty?

The paper commences with an examination of the relevant literature followed by a description of the methodology deployed to test the hypotheses. A discussion of the results leads on to consideration of the practical implications of the study. Finally, an outline of research limitations and recommendations for future research in the area are set out.

\section{Theory and Hypotheses}

\subsection{Environmental Uncertainty}

One of the earliest attempts to define uncertainty approached it from the perspective of differentiating between uncertainty and risk. Measurement was used by Knight (1921) to explicitly separate the notion of uncertainty from the notion of risk on the basis that the former construct is non-quantitative in nature whilst in the case of the latter, "the distribution of the outcome in a group of instances is known" (p. 49). A definitional approach to the separation of risk from uncertainty facilitates research in the area (Bettis and Thomas, 1990) but agreement on such definitions is not always forthcoming. Miller (1992) contended that "the strategic management field lacks a generally accepted definition of risk" (p. 311) and argued that uncertainty increases risk. Hence, there appears to be a certain predictability (if only probabilistic) or 'knowability' about risk which is not present in the case of uncertainty (Jones and Butler, 1992).

Environmental uncertainty has been studied from a perceptual perspective which contends that managerial perceptions shape management decisions (Mitchell et al, 2011; Sharfman and Dean, 1991), an objective perspective which treats the environment as an objective fact, independent of organisations (Tan and Litschet, 1994), and a socially enacted perspective which adopts an interpretivist perspective and argues that "conditions in the environment cannot be separated from perceptions of those conditions" (Hatch, 1997: 93).

Distinctions have been drawn between the content or sources of uncertainty and its dimensions or types. Wernerfelt and Karnani (1987), for example, identified four different sources of uncertainty (in order of importance), i.e. demand uncertainty (size of market, sales projections, etc.), supply uncertainty (exogenous or endogenous), competitive uncertainty and externalities (new entrants, etc.), and the effects of external factors (social pressures, government intervention, etc.). Whilst the source of the uncertainty can be associated with the domain of the environment which the decision-maker is uncertain about (e.g. competitors, technology, economy, etc.), the type of uncertainty delineates "the nature of the uncertainty being experienced" (Milliken, 1987: 136).

Reflecting Daft and colleagues' assertion that 'a single environmental measure may not be a useful way to understand how the environment influences organisational actions" (1988: 135), Milliken's (1987) re-examination of the construct of perceived environmental uncertainty ascribed some of the confusing results of past research in the area to a failure to differentiate between three types of environmental uncertainty; (1) state uncertainty (or perceived environmental uncertainty); what environmental changes are taking place that I should be aware of? Examples might include competitors' actions, government intervention or critical supply shortages; (2) effect uncertainty; will these changes impact on my organisation and if so, to what extent? and (3) response uncertainty; what response options are available and what is the value of each? Low levels of state uncertainty may mean high levels of effect and response uncertainty; similarly high levels of state uncertainty may mean low levels of effect and response uncertainty. High state uncertainty may affect both the process and content of strategy. Milliken contended that "it is not change per se or even a fast rate of change that creates uncertainty about the environment; rather, it is unpredictable change that will be associated with this type of uncertainty" (Milliken, 1987: 135).

When the response decision is eventually made and implemented, however, one can conceive of a fourth type of environmental uncertainty arising, viz. the outcome or effectiveness or success of the response (Gibbons and Chung, 1995). The key question here is: how do I know if my response has achieved its objectives? In the absence of some form of evaluation, organisations will be uncertain as to whether or not the desired outcome was achieved. Managers must measure and monitor decision outcomes; this is "an important first step in maintaining attention to critical strategic issues" (Shimizu and Hitt, 2004: 52). The decision-making process can be considered incomplete until some assessment is undertaken. This assessment will feed back into future approaches to addressing environmental uncertainty and hence contribute to organisational learning (Senge, 1990). 


\subsection{Strategic Decision-Making}

A strategic decision is one that is important, in terms of the actions taken, the resources committed or the precedents set (Eisenhardt and Zbaracki, 1992; Powell, 2011), it is a commitment to action and the resource allocations which determine the field of activity of the firm, what endeavours it pursues and what markets it serves (Mazzolini, 1981). The primary objective of strategic decision-making is to develop and support a lasting superior performance (Forbes, 2001; Thomas, 1984). Strategic decision-making is characterised by novelty, complexity and open-endedness (Mintzberg, et al, 1976), it is a multidimensional process (Miller and Friesen, 1977) and "a critically important aspect of top managers' jobs" (Milliken and Vollrath, 1991: 1229). Strategic decisions reflect how an organisation manages the interaction between itself and the environment and are embedded in both the organisation's inner and outer contexts (Elbanna, 2006; Mitchell et al, 2011).

Eisenhardt and Zbaracki (1992) classified the major strategic decision-making paradigms into comprehensive and bounded rationality, politics and power, and garbage can with the first two considered the essence of decision-making. These authors lamented the lack of clarity resulting from the confounding influence of moderating variables on strategic decision-making relationships with performance and called for researchers to deploy more proximate dependent variables; King (1983) made a similar call for more direct evaluations. This study seeks to answer these calls by minimising the distance between the measures of rationality and performance.

Strategic decision-making research has often been divided into two different but complementary streams (Elbanna, 2006), viz. content research and process research. Content research has dominated the literature over the last two decades and is concerned with the composition of strategy in terms of mergers, acquisitions, diversification and alignment with the environment. Process research deals with the way in which a strategic decision is made and implemented and the factors which influence it. In a major review of strategy-process research based on 227 articles, Hutzschenreuter and Kleindienst (2006) conclude that the field has achieved substantial progress and describe its "current intellectual landscape" (p. 710) along six perspectives: rational mechanistic, cognitive, upper echelon, middle management, organic, and micro. This study fits into the first of these perspectives and also reflects one of the future research agendas of previous reviews (i.e. Eisenhardt and Zbaracki's plea in 1992 for closer conceptual proximity between the constructs of decision-making and performance), the response to which by the academic community Hutzschenreuter and Kleindienst (2006) credits with accounting for "the advancement of the discipline" (p. 701).

A review of the literature over the past fifty years reveals the emergence of two broad schools of thought relating to the processes employed in making strategic decisions, viz. the 'rational-comprehensive' or 'synoptic formalism' school (Ansoff, 1965; Elbanna, 2006; Fredrickson, 1983) and the 'incremental-political' school (Quinn, 1980). The rationality approach - historically linked to Harvard, the 'design school' - consists of a systematic, analytical, and formal process which prescriptively follows an ordered, linear route (Fahey, 1981; Simon, 1979). Rationality is the use of information for the purpose of selecting a sensible alternative in the pursuit of one's goals (Hough and White, 2003). It is concerned with the extent to which decision makers follow a systematic process in reaching carefully thought-out goals (Hitt and Tyler, 1991). Under incrementalism, decisions are considered to 'emerge' along the lines of a 'building blocks' approach with consensus formation playing an important part (Markoczy, 2001; Wooldridge and Floyd, 1989); decisions come about through a process of iteration involving extensive lobbying, bargaining and debate (Quinn, 1980). Formulation and implementation take place simultaneously; the means (alternatives) and the ends (goals) processes are intertwined (Fredrickson, 1983). The incrementalist decision-maker breaks the problem down into sub-problems which are solved sequentially (Hunt, 1962).

Contradictory findings have resulted from studies which have examined the relationships between environmental uncertainty and rational strategic decision making processes (e.g. Bourgeois and Eisenhardt, 1988; Fredrickson and Mitchell, 1984; Mitchell et al, 2011; Papadakis, 1998). What these studies have in common, however, is a propensity to analyse the relationship from only one direction of influence, viz. from environmental uncertainty to rational strategic decision-making. Hence, there is a gap in our understanding of how rational processes can help strategists to manage uncertainty. This study attempts to rectify that situation not just in terms of the direction of influence but also by designing the conceptual model to ensure close proximity between rationality and performance, thereby providing a clearer picture of the relationship in responding to one of the items on Eisenhardt and Zbaracki's (1992) future research agenda.

\subsection{Entrepreneurial Orientation}

Miller (1983) defines an entrepreneurial firm as one that "engages in product market innovation, undertakes 
somewhat risky ventures and is first to come up with 'proactive' innovations, beating competitors to the punch" (p. 770). This description is reasonably similar to Mintzberg's (1973) entrepreneurial organisations and to Miles and Snow's (1978) prospector firms. The top managers of such firms demonstrate these entrepreneurial attributes through their strategic decisions and operating management philosophy (Covin and Slevin, 1989; Simsek et al, 2010). Between three and five of the dimensions of autonomy, innovativeness, competitive aggressiveness, risk-taking, and proactiveness have subsequently been used by researchers to measure the term 'entrepreneurial orientation', (including Covin and Slevin, 1989; Naman and Slevin, 1993; Richard et al, 2004; Slater et al, 2006). Autonomy relates to the actions of individuals or teams in establishing new business concepts or visions (Lyon et al, 2000), innovativeness reflects a firm's willingness to promote new ideas, novelty and creative solutions (Richard et al, 2004), competitive aggressiveness is concerned with the intensity of the combative posture adopted by firms reacting to competitive trends and market demands (Lyon et al, 2000; Rauch et al, 2009), risk-taking concerns a firm's propensity to take business-related chances with regard to strategic actions when faced with uncertainty (Richard et al, 2004), and proactiveness refers to a firm's initiative in seizing opportunities in the marketplace (Lumpkin and Dess, 2001). As these dimensions vary independently, firms may exhibit relatively high levels of some and at the same time relatively low levels of others (Richard et al, 2004). The three most commonly cited dimensions of entrepreneurial orientation - proactiveness, risk-taking and innovativeness - are used in this study (Covin and Wales, 2011).

Links between entrepreneurial orientation and environmental uncertainty revolve around the notion that the presence of uncertainty is conducive to innovative activities (Jones and Butler, 1992; Knight, 1921). The focus of past research in this interaction, however, exhibits a strong tendency to focus on how uncertainty influences entrepreneurial orientation (e.g. Russell and Russell, 1992) or how uncertainty combined with entrepreneurial orientation impacts on a dependent variable (e.g. Lumpkin and Dess, 2001), which leaves a literature gap in our understanding of the reverse directionality. The reason this gap is of importance stems from the potential of entrepreneurial approaches to afford decision-makers greater clarity and confidence in interpreting and managing perceived environmental uncertainty.

\subsection{Organisation Structure}

Mintzberg defined the structure of an organisation as "the sum total of the ways in which it divides its labor into distinct tasks and then achieves coordination among them" (Mintzberg, 1979: 2). Others have discussed its enduring and persistent qualities by describing its dominant feature as "patterned regularity" (Ranson et al 1980: 1). Formal structure is concerned with the documented, official relationships among firm members and informal structure describes the unofficial ones (Galan and Sanchez-Bueno, 2009; Mintzberg, 1979). Sixty years ago, Weber proclaimed that the bureaucratic organisation structure, characterised by rigid division of activities, clearly defined roles and hierarchically organised authority, was technically superiority to all other forms (Weber, 1947). Central to Weber's rationalisation of bureaucracy was the application and acceptance of impersonal rules (Child, 1972).

Almost fifteen years after Weber (1947), Burns and Stalker (1961) introduced the notion of two different types of structure, i.e. the mechanistic structure which is similar in features to Weber's bureaucracy and the organic structure which consists of more fluid and flexible working arrangements. Firms with mechanistic structures pursue centralised decision-making arrangements, strict enforcement of adherence to rules and procedures, rigid control over information content and flows, and carefully designed reporting relationships (Slevin and Covin, 1997). Organic structures, on the other hand, reflect an organisation's emphasis on delegation, participation, creativity, openness and adaptability (Brouthers et al, 2000).

Although numerous studies have been conducted which include the constructs of environmental uncertainty and organisation structure in their conceptual model (e.g. Brouthers et al, 2000; Sine et al, 2006), there is a dearth of literature with regard to the role that organisation structure plays in shaping environmental uncertainty.

\subsection{Hypotheses}

The key hypotheses are developed by examining how the independent variables influence each of the four components of perceived environmental uncertainty. State certainty is concerned with assessing "how things are and how they are changing" (Naylor, 2004: 238), often it involves the firm facing a radical, unpredictable change in its environmental context, e.g. economic regulation or privatisation (Cuervo-Cazurra, 2003). Firms with a willingness to foster change and innovation may approach environmental uncertainty in a more confident and combative manner (Naman and Slevin, 1993). Furthermore, the inclusive nature of the rational approach suggests a decentralised structure which in turn tends to be associated with the organic form. Hence:

Hypothesis 1: Rationality, entrepreneurial orientation and organic organisation structure will have a positive 
relationship with State certainty.

Effect uncertainty is an inability to predict the nature of the effect of a future state of the environment on the organisation (Buchko, 1994: 411). Hence:

Hypothesis 2: Rationality, entrepreneurial orientation and organic organisation structure will have a positive relationship with Effect certainty.

Response uncertainty operates at the individual decision level and usually involves an immediate decision as a threat or opportunity may be imminent (Milliken, 1987). Hence:

Hypothesis 3: Rationality, entrepreneurial orientation and organic organisation structure will have a positive relationship with Response certainty.

Having made a response, the organisation is now faced with the prospect of assessing its impact and hence is uncertain as to whether or not its response has had the desired effect:

Hypothesis 4: Rationality, entrepreneurial orientation and organic organisation structure will have a positive relationship with Outcome certainty.

Four additional variables were included in the research model to act as control variables on the basis of their potential influence on perceived environmental uncertainty, viz. organisation size (Goll and Rasheed, 1997), performance (Agle et al, 2006; Elbanna and Child, 2007; Mani et al, 2007), environmental heterogeneity (Wiklund and Shepherd, 2003) and resource dependence (Milliken, 1990) (see Figure 1).

Insert Figure 1- here

\section{Methodology}

The conceptual model developed for this research involved building up a picture of the relationships between the variables in a nested, integrated manner with perceived environmental uncertainty as the criterion variable (Figure 1). This model also positioned rationality in close proximity to performance (Eisenhardt and Zbaracki, 1992). A survey instrument was utilised to test the hypotheses and the constructs were operationalised, in the main, on the basis of previous studies. The recent trends of commercialisation, privatisation and deregulation combined with the capital-intensive nature of the business make the European Airport Industry a particularly suitable candidate for the empirical component of this study. The unit of analysis therefore is at the organisational level (Dess and Rasheed, 1991) and the targeted respondent had to be familiar with both the external environment and the strategic decision-making processes of the organisation.

\subsection{Measures}

The approach taken reflects the examination of environmental certainty as a perceptual phenomenon, a property of organisation executives (Starbuck, 1976; Milliken, 1990). Each type of certainty was measured independently and for each scale, a higher score means that the environment is more certain. Respondents were given a projected independent event relating to a specific change in the environment which is of considerable strategic importance to the senior management of all European airports, i.e. the projected doubling of demand within fifteen years. Hence, in line with Milliken's approach (1990), an objective reality was used to stimulate perceptual responses (Shafman and Dean, 1991). To assess the accuracy of this demand projection (state certainty), respondents were asked to indicate its likelihood of occurrence on a scale of $0 \%$ to $100 \%$ and then asked to indicate their level of confidence in this estimate. A similar composite ratings approach was used to measure the impact of this demand forecast (effect certainty) on each airport by asking each respondent for an estimate $(0 \%$ to $100 \%)$ of the extent to which their airport would be affected by this growth followed by an indication of their certainty of this estimate (one-item, seven-point Likert scale similar to that used in state certainty measure above). This effect certainty score was then "weighted by factor for perceived magnitude of effect" (Milliken, 1990: 51). Response certainty was measured by adapting Milliken's (1990) six-item, five-point scale and was found to have a Cronbach alpha coefficient of 0.69 when one item with a low item-total correlation was omitted. To measure the effectiveness of the response (outcome certainty), a new six-item, five point scale was developed for this research. The items were designed to test how organisations determined if their responses to a change in the environment had the desired result.

Rationality of strategic decision-making processes was measured with a five-item scale adapted from Atuahene-Gima and Li (2004) who had in turn adapted it from Miller and colleagues (1998). The wording was also influenced by Goll and Rasheed (1997) and included: "my airport explicitly emphasizes consideration of many different criteria before deciding on a specific course of action" using a five-point scale from $1=$ strongly disagree to $5=$ strongly agree $(\alpha=0.88)$. Entrepreneurial orientation is an aggregate measure based on the three 
dimensions of innovation, risk-taking and acting proactively and was measured with the nine-item, seven-point scale used by Covin and Slevin (1989) and Richard and colleagues (2004). The Cronbach alpha result was 0.87 (with one item deleted). The measure for organisation structure was based on the mechanistic/organic continuum of Burns and Stalker (1961) and was previously successfully used by Covin and Slevin (1989), Slevin and Covin (1997), and Brouthers and colleagues (2000). A Cronbach alpha of 0.80 was recorded.

The overall average Cronbach alpha coefficient for the five multi-item measures (i.e. response certainty, outcome certainty, rational strategic decision-making, organisation structure and entrepreneurial orientation) used in this study is 0.77 . This compares favourably with the mean result reported by Miller and Friesen and so "construct reliability therefore appeared to be very acceptable" (1982: 7).

The control variables were measured as follows; organisation size was assessed using the total number of passengers who used the airport in the previous year; for performance the average rate of growth in passenger numbers over the previous three years was used (Greve, 2011), environmental heterogeneity was measured by identifying for each responding airport the market share of the two principal types of airline customer which airport managers deal with, i.e. full-service carriers and low-fare carriers (Barrett, 2004), and resource dependence was measured as the difference between last year's passenger volume and capacity for each airport (Wan and Yiu, 2009).

\subsection{Response Rate}

The strategies deployed to increase response rates included topic salience and social network sponsorship (Cycyota and Harrison, 2006). In order to establish that the data collected was of a sufficiently high quality to be used for deriving robust results, it was subjected to detailed analysis for nonresponse bias, common method variance, and normality. In addition, the validity of the data was also enhanced by emphasising the importance of the research to respondents, assuring confidentiality, and offering a copy of the main findings (Atuahene-Gima and $\mathrm{Li}, 2004)$. The number of completed questionnaires returned represented 98 individual airports from 29 European countries, a response rate of $24 \%$ on the basis of the target population (Hmieleske and Baron, 2009). In terms of size, the mean for responding airports was 5.1 million passengers (standard deviation of 8.3). Geographically, $64 \%$ of the 45 European countries were represented.

\section{Findings}

The results of this study provide good support for the broad thrust of its hypotheses (see Table 1).

\section{Insert Table 1- here}

State certainty: a strong relationship was found between rational strategic decision-making and this component of perceived environmental uncertainty, thus providing partial support for Hypothesis 1. Effect certainty: organisation structure was found to be the most significant predictor of effect certainty, thus providing partial support for Hypothesis 2. Response certainty: no support was found for Hypothesis 3. Outcome certainty: A significant relationship was demonstrated between the two predictor variables of rationality and entrepreneurial orientation and outcome certainty, thus providing support for Hypothesis 4.

The explanatory power of the integrated research model, i.e. $42 \%$, compares favourably with the results of similar studies (e.g. Elbanna and Child, 2007; Goll and Rasheed, 1997; Milliken, 1990). The principal findings are that the decomposition of the construct of environmental uncertainty into four differentiable parts has been found to have methodological merit and the three predictor variables of rationality, entrepreneurial orientation and organisation structure have been shown to shape the four parts in different ways. Milliken's $(1987,1990)$ dis-aggregation of uncertainty into empirically distinct parts is supported. The positioning of perceived environmental uncertainty as the dependent variable sheds new light on its influencing variables and confirms its pivotal role in our understanding of strategic management.

Hence, the environmental interpretation process may involve top managers experiencing several different types of uncertainty which suggests that environmental uncertainty is a much more complex construct than its traditional, unidimensional role as a contingent variable would indicate.

\section{Discussion}

Although numerous previous studies have included the concepts of environmental uncertainty and rational strategic decision-making processes, none are strictly comparable with this research as here perceived environmental uncertainty is positioned as the dependent or criterion variable and is decomposed into four distinct parts. Hence, Goll and Rasheed (1997) for example found that environmental dynamism (corresponding to state uncertainty in its operationalisation) moderated the relationship between rationality and performance 
with no bivariate correlation between rationality and environmental dynamism. By contrast, this research finds a significant direct correlation between rationality and state certainty indicating that organisations that use rational strategic decision-making processes are more confident that they understand changing patterns in their external environment. Such high levels of confidence are associated with an analytical approach to decision-making, a strong entrepreneurial orientation and an organic organisation structure.

The suggestion from the result suggesting organisation structure as a predictor of effect uncertainty is that firms with organic structures are more certain of the impact that a particular environmental change will have on their organisation. Hence, as top-level managers are engaged in the judgemental task of determining the effect of an environmental threat or opportunity, decentralised structures will process the required information more efficiently. This is consistent with the findings of previous research suggesting that the characteristics of organisations can influence the environmental perception process (e.g. Leifer and Huber, 1977; Milliken, 1987, 1990). The significant correlation identified between rationality and outcome certainty makes for interesting contrasts with the findings of Elbanna and Child's $(2007$; 2007a) analysis of Egyptian decision-making which demonstrated highly significant negative correlations between rationality and both environmental uncertainty (more closely connected with state and effect certainties in this study) and decision uncertainty (contains elements of both response and outcome certainties in this study) and a highly significant positive link with strategic decision effectiveness (operationalised relatively closely to outcome certainty in terms of generating desirable outcomes). This third finding corresponds most approximately with the result of this research. Elbanna and Child (2007) also found that performance moderated the rationality - effectiveness link which is consistent with this study (substituting outcome certainty for strategic decision effectiveness).

\section{Conclusion}

In summary, the results show that a fourth type of certainty can be meaningfully measured and added to the existing three-part framework, that the four types should be treated as separate constructs, and that rational strategic decision-making, entrepreneurial orientation and organic organisation structures are positively related to perceived environmental certainty. Moreover, these variables exert differing levels of influence at different stages of the interpretation process. Hence, as executives adapt the organisation to its environment, they may experience different types of uncertainty and such differences could be masked by the traditional adoption of an aggregated, unidimensional measure of perceived environmental uncertainty.

\subsection{Managerial Implications}

Top managers need to be conscious of the type of uncertainty which they are dealing with as different sources of uncertainty create different information processing demands. Moreover, the level of confidence associated with each type of uncertainty may differ according to the nature of the event. Thus, the process of environmental interpretation requires organisations to have the capacity to experience several different types of uncertainty related to several different types of events simultaneously as they attempt to achieve and maintain an organisation/environment fit. In addition, executives should be aware of the organisational characteristics which influence their management of the different types of uncertainty. Top managers, for example, may find that an analytical approach to strategic decision-making results in increased confidence in the process of identifying and understanding significant changes in the external environment. Finally, adopting a proactive, innovative and risk-taking approach will also increase executives' confidence that they can evaluate the extent to which the objectives of their responses to those environmental threats and opportunities are achieved.

\subsection{Limitations}

Although carefully designed, the interpretation of findings from this research should be informed by the following limitations. Firstly, the survey approach may not be as fine-grained as a case study approach (Eisenhardt, 1989) and the phenomena of interest may not be accurately captured by the perceptual self-report measures deployed (Elbanna and Child, 2007). Secondly, the cross-sectional design used here is time dependent and makes causal relationships difficult to sustain (Hoque, 2004), longitudinal studies, on the other hand, can greatly reduce the possibility of reverse-causality between the key variables (Goll and Rasheed, 1997). Thirdly, the single pre-selected event used to measure uncertainty may not have adequately captured the external environment. As the industry had already been experiencing demand growth for some time and as all forecasts indicated more to come, the level of uncertainty associated with this particular element of the environment may have been much less than in the case of, for example, security or regulatory issues. Fourthly, a single respondent approach may not be representative of the company view and may result in systematic response bias (Ketokivi and Schroeder, 2004) but this must be considered in the context of the increasing difficulty involved in obtaining more than one response per firm, particularly at senior executive level (Cycyota and Harrison, 2006). 


\subsection{Future Research}

Although Milliken (1987; 1990) identified the need to disaggregate the concept of environmental uncertainty into distinct parts in order to clarify our understanding of its role in managing a business and this study sought to take the analysis a step further by extending the typology with the addition of a fourth, distinct component, perhaps the story does not end there? Might there be a fifth component entitled, for example, 'corrected response'. Moreover, although learning has previously been identified as an important component of the environmental interpretation process (e.g. Daft and Weick, 1984; Milliken, 1990), measuring the feedback loop to assess exactly how the learning obtained from dealing with one significant environmental change manifests itself in identifying and addressing the next one could be a promising avenue for future research.

\section{References}

Agle, B. R., Nagarajan, N. J., Sonnenfeld, J. A., \& Srinivasan, D. (2006). Does CEO Charisma Matter? An Empirical Analysis of the Relationships among Organizational Performance, Environmental Uncertainty and Top Management Team Perceptions of CEO Charisma. Academy of Management Journal, 49(1), 161-174. http://dx.doi.org/10.5465/AMJ.2006.20785800

Ansoff, I. H. (1965). Corporate Strategy. New York : McGraw-Hill.

Atuahene-Gima, K., \& Li, H. (2004). Strategic Decision Comprehensiveness and New Product Development Outcomes in New Technology Ventures. Academy of Management Journal, 47(4), 583-597. http://dx.doi.org/10.2307/20159603

Barrett, S. D. (2004). How do the demands for airport services differ between full-service carriers and low-cost carriers? Journal of Air Transport Management, $10(1), \quad 33-39$. http://dx.doi.org/10.1016/j.jairtraman.2003.10.006

Bettis, R. A., \& Thomas, H. (1990). Introduction in Risk, Strategy, and Management. Greenwich, Conn: JAI Press.

Bourgeois, L. J III., \& Eisenhardt, K. M. (1988). Strategy Decision Processes in High Velocity Environments: Four Cases in the Microcomputer Industry. Management Science, 34, 816-835. http://dx.doi.org/10.1287/mnsc.34.7.816

Brouthers, K. D., Brouthers, L. E., \& Werner, S. (2000). Influences on Strategic Decision Making in the Dutch Financial Services Industry. Journal of Management, 26(5), 863-882. http://dx.doi.org/10.1177/014920630002600506

Buchko, A. A. (1994). Conceptualization and Measurement of Environmental Uncertainty: An Assessment of the Miles and Snow Perceived Environmental Uncertainty Scale. Academy of Management Journal, 37(2), 410-425. http://dx.doi.org/10.2307/256836

Burns, T., \& Stalker, G. M. (1961). The Management of Innovation. London: Tavistock.

Child, J. (1972). Organisational Structure, Environment, and Performance: The Role of Strategic Choice. Sociology, 6, 1-22. http://dx.doi.org/10.1177/003803857200600101

Covin, J. G., \& Slevin, D. P. (1989). Strategic Management of Small Firms in Hostile and Benign Environments. Strategic Management Journal, 10(1), 75-87. http://dx.doi.org/10.1002/smj.4250100107

Covin, J. G., \& Wales, W. J. (2011). The Measurement of Entrepreneurial Orientation. Entrepreneurship Theory and Practice, published online 1st March.

Cuervo-Cazurra, A. (2003). Transforming the Firm through Co-evolution of Resources and Scope, In Chakravarthy B., Mueller-Stewens G., Lorange P., \& Lechner C. (eds.), Strategy Process: Shaping the Contours of the Field. Blackwell Publishing.

Cycyota, C. S., \& Harrison, D. A. (2006). What (not) to expect when surveying Executives: A Meta-analysis of Top Manager Response Rates and Techniques over time. Organizational Research Methods, 9(2), 133-160. http://dx.doi.org/10.1177/1094428105280770

Daft, R. L., \& Weick, K. E. (1984). Towards a Model of Organisations as Interpretation Systems. Academy of Management Review, 9(2), 284-295.

Daft, R. L., Sormunem, J., \& Parks, D. (1988). Chief Executive Scanning, Environmental Characteristics and Company Performance: An Empirical Study. Strategic Management Journal, 9(2), 123-139. http://dx.doi.org/10.1002/smj.4250090204 
Dess, G. G., \& Rasheed, A. M. A. (1991). Conceptualising and Measuring Organisational Environments: A Critique and Suggestions. Journal of Management, 17(4), 701-710. http://dx.doi.org/10.1177/014920639101700404

Eisenhardt, K. M. (1989). Building Theories from Case Study Research. Academy of Management Review, 14(4), $532-50$.

Eisenhardt, K. M., \& Zbaracki, M. (1992). Strategic Decision Making. Strategic Management Journal, 13(Special Issue), 17-37. http://dx.doi.org/10.1002/smj.4250130904

Elbanna, S. (2006). Strategic Decision-Making: Process Perspectives. International Journal of Management Reviews, 8(1), 1-20. http://dx.doi.org/10.1111/j.1468-2370.2006.00118.x

Elbanna, S., \& Child, J. (2007). Influences on Strategic Decision Effectiveness. Strategic Management Journal, 18(4), 431-453. http://dx.doi.org/10.1002/smj.597

Fahey L. (1981). On Strategic Management Decision Processes. Strategic Management Journal, 2(1), 43-60. http://dx.doi.org/10.1002/smj.4250020105

Forbes, D. P. (2001). The Performance Implications of Strategic Decision Making: Evidence from a New Venture Context. Presented at 2001 Academy of Management Meeting, Washington, DC.

Fredrickson, J. W. (1983). Strategic Process Research: Questions and Recommendations. Academy of Management Review, 8(4), 565-575.

Fredrickson, J. W. (1984). The Comprehensiveness of Strategic Decision Processes: Extension, Observations, Future Directions. Academy of Management Journal, 27(3), 445-466. http://dx.doi.org/10.2307/256039

Fredrickson, J. W., \& Mitchell, T. R. (1984). Strategic Decision Processes: Comprehensiveness and Performance in an Industry with an Unstable Environment. Academy of Management Journal, 27(2), 399-423. http://dx.doi.org/10.2307/255932

Galan, J. I., \& Sanchez-Bueno, M. J. (2009). The Continuing Validity of the Strategic-Structure Nexus; New Findings, 1993-2003. Strategic Management Journal, 30(11), 1234-1243. http://dx.doi.org/10.1002/smj.782

Galbraith, J. R. (1973). Designing Complex Organisations. Mass: Addison-Wesley.

Gibbons, P. T., \& Chung, L. H. (1995). Defining Uncertainty: The Implications for Strategic Management. Irish Business and Administrative Research, 16, 17-32.

Goll, I., \& Rasheed, A. M. A. (1997). Rational Decision-Making and Firm Performance: The Moderating Role of Environment. Strategic Management Journal, http://dx.doi.org/10.1002/(SICI)1097-0266(199708)18:7<583::AID-SMJ907>3.0.CO;2-Z

Greve, H. R. (2011). Positional Rigidity: Low Performance and Resource Acquisition in Large and Small Firms. Strategic Management Journal, 32(1), 103-114. http://dx.doi.org/10.1002/smj.875

Hatch, M. J. (1997). Organization Theory: Modern, Symbolic and Postmodern Perspectives. New York: Oxford University Press.

Hitt, M., \& Tyler, B. (1991). Strategic Decision Models: Integrating Different Perspectives. Strategic Management Journal, 12(5), 327-352. http://dx.doi.org/10.1002/smj.4250120502.

Hmieleski, K. M., \& Baron, R. A. (2009). Entrepreneurs' Optimism and New venture Performance: a Social Cognitive Perspective. Academy of Management Journal, 52(3), 473-488. http://dx.doi.org/10.5465/AMJ.2009.41330755

Hoque, Z. (2004). A Contingency Model of the association between Strategy, Environmental Uncertainty and Performance Measurement: Impact on Organizational Performance. International Business Review, 13, 485-502. http://dx.doi.org/10.1016/j.ibusrev.2004.04.003

Hough, J. R., \& White, M. A. (2003). Environmental Dynamism and Strategic Decision-Making Rationality: An Examination at the Decision Level. Strategic Management Journal, 24(5), 481-489. http://dx.doi.org/10.1002/smj.303

Hunt, E. B. (1962). Concept Learning: An Information Processing Problem. New York: John Wiley and Sons. http://dx.doi.org/10.1037/13135-000

Hutzschenreuter, T., \& Kleindienst, I. (2006). Strategy-Process Research: What Have We Learned and What Is Still to Be Explored. Journal of Management, 32(5), 673-720. http://dx.doi.org/10.1177/0149206306291485 
Jones, G. R., \& Butler, J. E. (1992). Managing Internal Corporate Entrepreneurship: An Agency Theory Perspective. Journal of Management, 18(4), 733-749. http://dx.doi.org/10.1177/014920639201800408

Ketokivi, M. A., \& Schroeder, R. G. (2004). Perceptual Measures of Performance: Fact or Fiction?. Journal of Operations Management, 22(3), 247-264. http://dx.doi.org/10.1016/j.jom.2002.07.001

King, W. R. (1983). Evaluating Strategic Planning Systems. Strategic Management Journal, 4(3), 263-277. http://dx.doi.org/10.1002/smj.4250040307

Knight, F. H. (1921). Risk, Uncertainty, and Profit. Cambridge: The Riverside Press.

Kreiser, P., \& Marino, L. (2002). Analyzing the historical development of the environmental uncertainty construct. Management Decision, 40(9), 895-905. http://dx.doi.org/10.1108/00251740210441090

Leifer, R., \& Huber, G. P. (1977). Relations among Perceived Environmental Uncertainty, Organization Structure, and Boundary-Spanning Behavior. Administrative Science Quarterly, 22, 235-247. http://dx.doi.org/10.2307/2391958

Lumpkin, G. T., \& Dess, G. G. (2001). Linking Two Dimensions of Entrepreneurial Orientation to Firm Performance: The Moderating Role of Environment and Industry Life Cycle. Journal of Business Venturing, 10, 429-451. http://dx.doi.org/10.1016/S0883-9026(00)00048-3

Lyon, D. W., Lumpkin, G. T., \& Dess, G. G. (2000). Enhancing Entrepreneurial Orientation Research: Operationalizing and Measuring a Key Strategic Decision Making Process. Journal of Management, 26(5), 1055-1085. http://dx.doi.org/10.1177/014920630002600503

Mani, S., Anita, K. D., \& Rindfleisch, A. (2007). Entry Mode and Equity Level: A Multilevel Examnation of Foreign Direct Investment Ownership Structure. Strategic Management Journal, 28(8), 857-866. http://dx.doi.org/10.1002/smj.611

Markoczy, L. (2001). Consensus Formation during Strategic Change. Strategic Management Journal, 22(11), 1013-1031. http://dx.doi.org/10.1002/smj.193

Mazzolini, R. (1981). How Strategic Decisions are Made. Long Range Planning, 14(3), 85-96. http://dx.doi.org/10.1016/0024-6301(81)90187-4

Miles, R. E., \& Snow, C. C. (1978). Organisation Strategy, Structure, and Process. New York: McGraw-Hill.

Miller, C. C., Burke, L. M., \& Glick, W. H. (1998). Cognitive Diversity among Upper-Echelon Executives: Implications for Strategic Decision Processes. Strategic Management Journal, 19(1), 39-58. http://dx.doi.org/10.1002/(SICI)1097-0266(199801)19:1<39::AID-SMJ932>3.0.CO;2-A

Miller, D., \& Friesen, P. H. (1977). Strategy-Making in Context: Ten Empirical Archetypes. Journal of Management Studies, 14, 259-280.

Miller, D., \& Friesen, P. H. (1982). Innovation in Conservative and Entrepreneurial Firms Two Models of Strategic Momentum. Strategic Management Journal, 3(1), 1-25. http://dx.doi.org/10.1002/smj.4250030102

Miller, D., \& Friesen, P. H. (1983). Strategy-Making and Environment: The Third Link. Strategic Management Journal. 4(3), 221-235. http://dx.doi.org/10.1002/smj.4250040304

Miller, K. D. (1992). A Framework for Integrated Risk Management in International Business. Journal of International Business Studies, 23(2), 311-331. http://dx.doi.org/10.1057/palgrave.jibs.8490270

Milliken, F. J. (1987). Three Types of Perceived Uncertainty about the Environment: State, Effect and Response Uncertainty. Academy of Management Review, 12(1), 133-143.

Milliken, F. J. (1990). Perceiving and Interpreting Environmental Change: An Examination of College Administrators' Interpretation of Changing Demographics. Academy of Management Journal, 33(1), 42-63. http://dx.doi.org/10.2307/256351

Milliken, F. J., \& Vollrath, D. A. (1991). Strategic Decision-Making Tasks and Group Effectiveness: Insights from Theory and Research on Small Group Performance. Human Relations, 44(12), 1229-1253. http://dx.doi.org/10.1177/001872679104401201

Mintzberg, H. (1973). The Nature of Managerial Work. New York: Harper and Row.

Mintzberg, H. (1979). An Emerging Strategy of 'Direct' Research. Administrative Science Quarterly, 24(4), 582-589. http://dx.doi.org/10.2307/2392364

Mintzberg, H., Raisinghani, D., \& Theoret, A. (1976). The Structure of 'Unstructured' Decision Processes. 
Administrative Science Quarterly, 21(2), 246-275. http://dx.doi.org/10.2307/2392045

Mitchell, J. R., Shepherd, D. A., \& Sharfman M. P. (2011). Erratic Strategic Decisions: When and Why Managers are inconsistent in Strategic Decision Making. Strategic Management Journal, 32(7), 683-704. http://dx.doi.org/10.1002/smj.905

Naman, J. L., \& Slevin, D. P. (1993). Entrepreneurship and the Concept of Fit: A Model and Empirical Tests. Strategic Management Journal, 14(2), 137-153. http://dx.doi.org/10.1002/smj.4250140205

Naylor, J. (2004). Management. (2nd ed.). UK: Financial Times Press.

Papadakis, V. M. (1998). Strategic Investment Decision Processes and Organisational Performance: An Empirical Examination. British Journal of Management, 9, 115-132. http://dx.doi.org/10.1111/1467-8551.00078

Powell, T. C. (2011). Neurostrategy. Strategic Management Journal, 32(3), 1484-1499. http://dx.doi.org/10.1002/smj.969

Quinn, J. B. (1980). Strategies for Change - Logical Incrementalism. RD Irwin, Georgetown, Ontario.

Ranson, S., Hinings, B., \& Greenwood, R. (1980). The Structuring of Organizational Structures. Administrative Science Quarterly, 25(1), 1-17. http://dx.doi.org/10.2307/2392223

Rauch, A., Wiklund, J., Lumpkin G. T., \& Frese, M. (2009). Entrepreneurial Orientation and Business Performance: An Assessment of Past Research and Suggestions for the Future. Entrepreneurship Theory and Practice, 33(3), 761-787. http://dx.doi.org/10.1111/j.1540-6520.2009.00308.x

Richard, O. C., Barnett, T., Dwyer, S., \& Chadwick, K. (2004). Cultural Diversity in Management, Firm Performance, and the Moderating Role of Entrepreneurial Orientation Dimensions. Academy of Management Journal, 32(4), 745-772.

Russell, R. D., \& Russell, C. J. (1992). An Examination of the Effects of Organizational Norms, Organizational Structure, and Environmental Uncertainty on Entrepreneurial Strategy. Journal of Management, 18(4), 639-656. http://dx.doi.org/10.1177/014920639201800403

Senge, P. M. (1990). The Fifth Discipline: The Art and Practice of the Learning Organization. London: Century.

Sharfman, M. P., \& Dean, J. W. (1991). Conceptualising and Measuring the Organizational Environment: A $\begin{array}{llll}\text { Multidimensional Approach. Journal of } & \text { Management, } & \text { 17(4), }\end{array}$ http://dx.doi.org/10.1177/014920639101700403

Shimizu, K., \& Hitt, M. A. (2004) Strategic Flexibility: Organizational Preparedness to Reverse Ineffective Strategic Decisions. Academy of Management Executive, 18(4), 44-59. http://dx.doi.org/10.5465/AME.2004.15268683

Simon, H. A. (1979). Rational Decision Making in Business Organizations. American Economic Review, September, 493-513.

Simsek, Z., Heavey, C., \& Veiga, J. F. (2010). The Impact of CEO core Self-evaluation on the Firm's Entrepreneurial Orientation. Strategic Management Journal, 31(1), 110-119. http://dx.doi.org/10.1002/smj.800

Sine, W. D., Mitsuhashi, H., \& Kirsch, D. A. (2006). Revisiting Burns and Stalker: Formal Structure and New Venture Performance in Emerging Economic Sectors. Academy of Management Journal, 49(1), 121-132. http://dx.doi.org/10.5465/AMJ.2006.20785590

Slater, S. F., Olson, E. M., \& Hult, G. T. M. (2006). The Moderating Influence of Strategic Orientation on the Strategy Formation Capability - Performance Relationship. Strategic Management Journal, 27(2), 1221-1231. http://dx.doi.org/10.1002/smj.569

Slevin, D. P., \& Covin, J. G. (1997). Strategy Formation Patterns, Performance, and the Significance of Context. Journal of Management, 23(2), 189-209.

Starbuck, W. H. (1976). Organizations and their Environments. In M. Dunnette (Ed.), Handbook of Industrial and Organizational Psychology, 1069-1124. Chicago Rand McNally.

Tan, J., \& Litschert, R. J. (1994). Environment-Strategy Relationship and Its Performance Implications: An Empirical Study of the Chinese Electronics Industry. Strategic Management Journal, 15(1), 1-20. http://dx.doi.org/10.1002/smj.4250150102

Thomas, H. (1984). Strategic Decision Analysis: Applied Decision Analysis and Its Role in the Strategic Management Process. Strategic Management Journal, 5(2), 139-156. http://dx.doi.org/10.1002/smj.4250050205 
Thompson, J. D. (1967). Organisations in Action. New York: McGraw Hill.

Vassilis, M. Papadakis. (1998).Strategic Investment Decision Processes and Organizational Performance: An Empirical Examination. British Journal of Management, 9(2), 115-132. http://dx.doi.org/10.1111/1467-8551.00078

Wan, W. P., \& Yiu, D. W. (2009). From crisis to opportunity: environmental jolt, corporate acquisitions, and firm performance. Strategic Management Journal, 30(7), 791-801. http://dx.doi.org/10.1002/smj.744

Weber, M. (1947). The Theory of Social and Economic Organization. New York: Oxford.

Wernerfelt, B., \& Karnani, A. (1987). Competitive Strategy under Uncertainty. Strategic Management Journal, 8(2), 187-194. http://dx.doi.org/10.1002/smj.4250080209

Wooldridge, B., \& Floyd, S. W. (1989). Strategic Process Effects on Consensus. Strategic Management Journal, 10(3), 295-302. http://dx.doi.org/10.1002/smj.4250100308

Table 1. Means, Standard Deviations and Correlations among Variables

\begin{tabular}{|c|c|c|c|c|c|c|c|c|c|c|c|c|}
\hline Variable $^{\mathrm{a}}$ & Mean & S.D. & 1 & 2 & 3 & 4 & 5 & 6 & 7 & 8 & 9 & 10 \\
\hline State Certainty & 375.3 & 135.5 & & & & & & & & & & \\
\hline Effect Certainty & 454.7 & 192.5 & $0.36^{* *}$ & & & & & & & & & \\
\hline Response Cert. & 3.045 & 0.633 & 0.13 & 0.17 & & & & & & & & \\
\hline Outcome Cert. & 3.185 & 0.548 & $0.23^{*}$ & 0.07 & $0.44^{* *}$ & & & & & & & \\
\hline Rationality & 3.582 & 0.672 & $0.27^{* *}$ & 0.09 & 0.02 & $0.25^{*}$ & & & & & & \\
\hline Org. Structure & 3.677 & 0.970 & 0.14 & $0.23^{*}$ & 0.03 & 0.09 & 0.01 & & & & & \\
\hline Entrepren. Or. & 3.779 & 1.01 & 0.19 & 0.12 & 0.03 & $0.25^{*}$ & 0.17 & $0.54^{* *}$ & & & & \\
\hline Performance & 16.73 & 31.65 & 0.05 & 0.10 & -0.12 & -0.13 & -0.0 & -0.01 & -0.07 & & & \\
\hline Size & 5.084 & 8.382 & $0.30^{* *}$ & 0.14 & $0.31^{* *}$ & 0.11 & 0.02 & -0.03 & 0.16 & -0.1 & & \\
\hline Res. Depend. & 1.80 & 3.50 & $0.20^{*}$ & 0.06 & $0.39^{* *}$ & $0.33^{* *}$ & 0.06 & 0.06 & $0.22^{*}$ & -0.1 & $0.57^{* *}$ & \\
\hline Env.Heterogen. & 11.24 & 8.79 & 0.05 & 0.06 & 0.15 & 0.14 & -0.01 & -0.03 & -0.01 & -0.15 & 0.07 & 0.06 \\
\hline
\end{tabular}

$* \mathrm{p}<0.05$ level (2-tailed), $* * \mathrm{p}<0.01$ level (2-tailed). $\mathrm{N}=98$.

a. The means and standard deviations of the various types of certainty are not standardised.

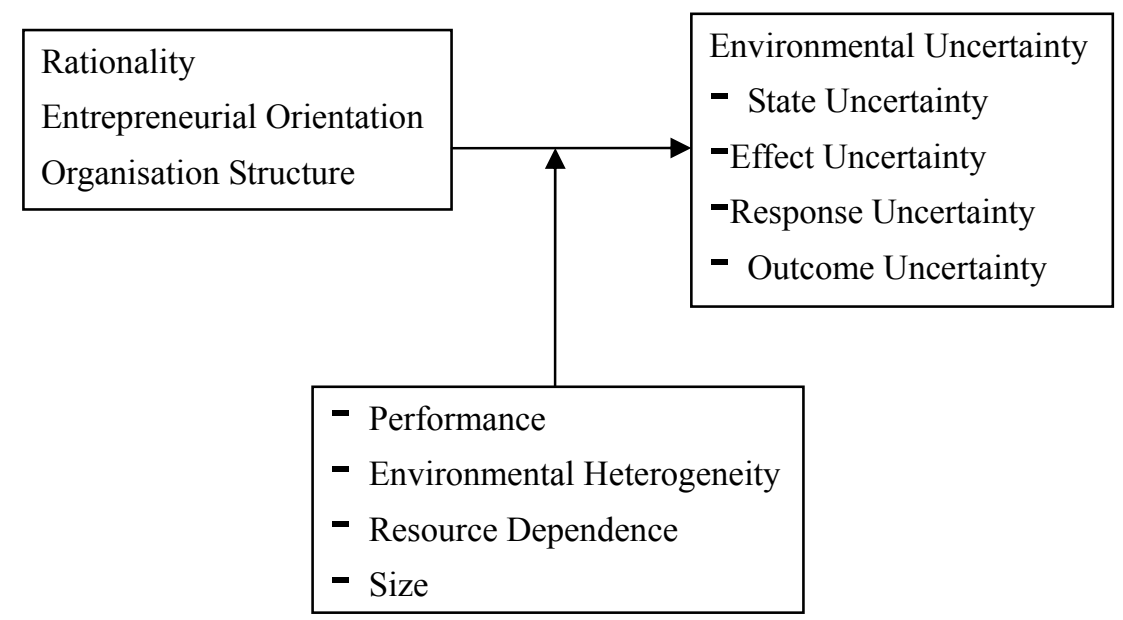

Figure 1. Conceptual Model 